\title{
How to Win the Olympic Games - The Empirics of Key Success Factors of Olympic Bids
}

\author{
Arne Feddersen ${ }^{\dagger}$,Wolfgang Maennig ${ }^{\dagger \dagger}$, and Philipp Zimmermann ${ }^{\dagger+\dagger}$
}

April 2007

\begin{abstract}
This paper examines the probability of the success of city bid campaigns on the basis of the quantified factors of a total of 43 bids for the Summer Olympic Games between 1992 and 2012. By using a model with the distance of the sporting venues to the Olympic Village, the local temperatures and unemployment rates, we can correctly predict the decision in $97 \%$ of failed bids and in $60 \%$ of successful bids.
\end{abstract}

JEL Classification Codes: L83, C25

Keywords: Olympic Games, Bidding process, Key success factors, Binary logistical regression

This paper is also available as University of Hamburg Working Paper Series in Economic Policy, Number 02/2007.

${ }^{\dagger}$ University of Hamburg, Department of Economics, Chair for Economic Policy, phone: 040 - 42838 - 4628, fax: 040 - 42838 - 6251, feddersen@econ.uni-hamburg.de

${ }^{+\dagger}$ University of Hamburg, Chair for Economic Policy, Von-Melle-Park 5, 20146 Hamburg, Germany, E-mail: maennig@econ.uni-hamburg.de, phone: +49 (0)40 42838 - 4622, fax: $+49(0) 4042838$ - 6251

${ }^{\dagger+}$ University of Hamburg 


\title{
How to Win the Olympic Games - The Empirics of Key Success Factors of Olympic Bids
}

\begin{abstract}
This paper examines the probability of the success of city bid campaigns on the basis of the quantified factors of a total of 43 bids for the Summer Olympic Games between 1992 and 2012. By using a model with the distance of the sporting venues to the Olympic Village, the local temperatures and unemployment rates, we can correctly predict the decision in $97 \%$ of failed bids and in $60 \%$ of successful bids.
\end{abstract}

Keywords: Olympic Games, Bidding process, Key success factors, Binary logistical regression JEL classification: L83, C25

Version: January 2007

\section{Introduction}

The hosting of the Olympic Games supposedly affects the regions involved in different ways - politically, psychologically, sociologically and culturally, as well as economically. ${ }^{1}$ Applications to host the Olympic Games (or other so-called "mega-events",2) by cities and regions are based, in as much as rational decision making may be presupposed, on the expectation that the corresponding benefits will exceed the costs. ${ }^{3}$ As for the members of the International Olympic Committee (IOC) who decide which cities will host the Olympic Games, in recent years at least they have received an evaluation

* University of Hamburg, Department of Economics, Chair for Economic Policy, phone: 040 - 42838 4628, fax: 040 - 42838 - 6251, feddersen@econ.uni-hamburg.de.

1 See Ritchie and Yangzhou (1987), Hotchkiss, Moore and Zobey (2003) and Baade and Matheson (2002) for ex-post analysis of the economics of the Games of Atlanta 1996 and L.A. 1984 and the literature quoted therein for the corresponding ex-ante analysis.

2 "Throughout the 1980s, World's Fairs and Olympic organizers turned to the mega-event as a panacea, a solution to the myriad of problems caused by economic hard times" (Tews 1993, p. 3, quoted in Baade and Matheson 2002, p. 129).

3 See Spilling (1996, p. 321). For an overwiew on ex ante studies on the costs and benefits of the Olympics cf. Preuss (2004, p. 45). Benefits may also occur in the case of failed applications. Thus the international application campaign may in part be seen as a relatively cheap form of image campaign (Andranovich, Burbank and Heying 2001, p. 127). For example, the value of Birmingham's (unsuccessful) bid has been estimated at 25 million BP, although it only cost 5 milion BP (Roche 2001, p. 587). 
report which compares the most important determinants for the individual cities in question.

In spite of this assumed rationality both on the part of the applicants and of the decisionmakers, the process of deciding who will host the Olympic Games has so far attracted relatively little attention in economic analyses. Schauenberg (1992) analyses the voting procedure for the 1996 Olympic Games and reveals some irrationalities. Swart and Bob (2004) identify factors as accountability, political support, relationship marketing, ability, infrastructure, bid team composition, communication and exposure and existing facilities as decisive for a successful bid. However, these factors are not submitted to any econometric test. This limited attention is astonishing because - presumably as a consequence of the expected benefits - both the number of applicant cities and the related expenditure of resources have increased significantly. ${ }^{4}$

This paper examines, in our opinion for the first time, the probability of success of application campaigns to host the Olympic Summer Games ${ }^{5}$ on the basis of quantified determinants. The analysis is based on a total of 43 bids to host the Olympic Summer Games between 1992 and 2012. Section 2 sketches the history of the bids and the awarding of the Games. Section 3 presents the data, the estimation model and the results of the econometric analysis. Section 4 closes with a conclusion.

\section{Some elements of the history of Olympic bids}

Table 1 provides an overview of the years and locations in which the Summer Olympic Games have been held, the year of the IOC's bid decision and the other unsuccessful applicant cities. The figures are taken from Lyberg (1996, p. 252-260) as well as from our own updating research, in which only those cities are considered as applicants that actually featured in the voting process (or which withdrew their applications for what-

4 The application budget for LA 1984 was 158,000 US-\$ (Andranovich, Burbank, Heying 2001, p. 118). The budget for London 2012 was 29.1 million BP, of which 1.4 million BP was not spent (N.N. 2005).

5 The Olympic Winter Games have to be analysed separately given their particular climatic and topographic requirements. 
ever reasons shortly before the vote took place). Scherer (1995, p. 401) by contrast departs from this approach and defines every city as an applicant that expressed its interest to the IOC to host the Olympics, and thus arrives at considerably higher numbers of applicants.

With regard to the following analysis it appears meaningful to systematise the history of Olympic bids particularly according to the criterion of the absolute number of applicant cities (and the changes to this number) in the various phases, even if other systems, e.g. according to political and/or historical principles, also appear possible (cf. for example Guttmann 1992).

In an initial phase from 1886 to the end of WW II the awarding of the Games was largely determined by the influence of the founders of the modern Olympics. A total of 39 cities applied to host the 14 Olympic Games of the period. The second phase, which began after WW II and lasted until 1968, shows a significant rise in the numbers of applicant cities $^{6}$ and, with the decision in favour of Tokyo's bid to host the 1964 Games, also includes for the first time an opening up of the club of host cities which had previously been limited to those from western cultural circles. The awarding of the 1968 Games to Mexico City is partly regarded as an attempt by the IOC to avoid both the effects of the East-West conflict that had intensified during the Fifties and increasing damage from boycotts. ${ }^{7}$ The 1964 Olympic Games in Tokyo, which were used to improve sporting and general infrastructure to a previously unheard of degree and which also entailed considerable costs, initiated a process of rethinking among applicant cities (Greenberg 2003, p. 36).

6 A total of 37 cities applied to host the six Olympic Games held in this phase.

7 Cf. Liu (1998, p. 85). The Montreal Games were boycotted by the teams of 20 black African states in protest against the participation of New Zealand, whose national rugby team had visited South Africa (Greenberg 2003, p. 43). Following the Soviet Union's invasion of Afghanistan 36 countries boycotted the 1980 Games in Moscow; a further 20 NOCs did not comment on the invitation (Schollmeier 2001, p. 23). Finally, seven socialist states refused to participate in the Los Angeles Games. For an overview of boycotts and exclusions as a means of political pressure that heavily influenced the Olympic Games from 1956 onwards, cf. Riordan, Lowe and Nikishkinov (1980). 
The third phase from 1972 up to and including $1988^{8}$ accordingly displays a degressive tendency in the number of applicants, which almost exclusively came from the industrially more developed countries. Twelve bids by eight different cities were made for the five Olympic Games of this phase. This third phase can be characterised as displaying a limited intensity of competition to host the Olympic Games. The third phase did however influence competitive behaviour in phase 4, since the Games in Los Angeles and Seoul were regarded as financially successful and induced a rise in the number of applicants. The end of the East-West conflict from the late Eighties meant that the Olympic Games have since hardly been used as a political instrument at all. The applicant cities have accordingly once again been able to hope for greater image gains from the Olympics.

Phase 5 begins with the revelation of the IOC corruption scandal of Salt Lake City and with the awarding of the 2008 Olympic Games in the year 2001. The repercussions of the scandal led to fundamental changes ${ }^{9}$ which, with the division of the application process into two phases (the "applicant city phase" and the "candidate city phase") were intended to provide greater transparency. In addition the IOC, under its new president Jacques Rogge, has set itself the target of reducing the costs and the size of the Olympic Games (Waldbröl 2003). A further increase in the numbers of applicants hoping to host the two Olympic Games in this fifth phase from 2008 to - so far - 2012, can be seen in comparison with the previous phases. The nineteen bids for the two Olympic Summer Games make it evident that the Olympic Games are currently enjoying greater popularity than ever before among applicant cities.

Illustration 1 summarizes the development of the numbers of applicants in the five phases. The upwards trend in applicant numbers in the second phase can be seen clearly, with more than double the number of applicants per Olympic Games than in the first

8 The period of time between the vote on the host city and the hosting of the Games, which is not constant over the history of the Games and which can be up to seven years, should be taken into account here and in the following.

9 For a description and an economic analysis of corruptive process around Salt Lake City and the institutional changes afterwards Maennig (2002). 
phase. The degressive development in bid numbers in the third phase and the renewed rise in bid numbers since the fourth phase are also clearly noticeable. 
Table 1: History of Olympic bids

\begin{tabular}{|c|c|c|c|c|}
\hline & Election & Olympics & Host City & Contender \\
\hline Phase 1 & $\begin{array}{l}1894 \\
1894 \\
1902 \\
\\
1903 \\
1909 \\
1912 \\
1919 \\
1921 \\
1921 \\
1923 \\
1931 \\
1936 \\
1939\end{array}$ & $\begin{array}{l}1896 \\
1900 \\
1904 \\
1906 \\
1908 \\
1912 \\
1916 \\
1920 \\
1924 \\
1928 \\
1932 \\
1936 \\
1940 \\
1944\end{array}$ & $\begin{array}{l}\text { Athens } \\
\text { Paris } \\
\text { St. Louis } \\
\text { Athens } \\
\text { London } \\
\text { Stockholm } \\
\text { Berlin }^{c} \\
\text { Antwerp } \\
\text { Paris } \\
\text { Amsterdam } \\
\text { Los Angeles } \\
\text { Berlin } \\
\text { Helsinki }^{c} \\
\text { London }^{c}\end{array}$ & $\begin{array}{l}\text { Buffalo/ Chicago } \\
\\
\text { Berlin }^{\mathrm{a}} / \text { Mailand/ Rom }^{\mathrm{b}} / \text { Turin } \\
\text { Berlin }^{\mathrm{a}} \\
\text { Alexandria }^{\mathrm{a}} / \text { Budapest }^{\mathrm{a}} \\
\text { Amsterdam }^{\mathrm{a}} / \text { Lyon }^{\mathrm{a}} \\
\text { Amsterdam/ Barcelona/ Los Angeles/ Prague/ } \\
\text { Rome } \\
\text { Los Angeles } \\
\text { Barcelona/ Budapest }^{\mathrm{a}} \text { / Rome } \\
\text { Tokyo }^{\mathrm{b}} \\
\text { Detroit/ Helsinki/ Lausanne/ Rome }^{\mathrm{a}}\end{array}$ \\
\hline Phase 2 & $\begin{array}{r}1946 \\
1947 \\
1949\end{array}$ & $\begin{array}{l}1948 \\
1952 \\
1956\end{array}$ & $\begin{array}{l}\text { London } \\
\text { Helsinki } \\
\text { Melbourne } \\
\text { Stockholm } \\
\text { Rom } \\
\text { Tokyo } \\
\text { Mexico City }\end{array}$ & $\begin{array}{l}\text { Baltimore/ Lausanne/ Los Angeles/ } \\
\text { Minneapolis/ Philadelphia } \\
\text { Amsterdam/ Chicago/ Detroit/ Los Angeles/ } \\
\text { Minneapolis/Philadelphia } \\
\text { Buenos Aires/ Chicago/ Detroit/ Los Angeles/ } \\
\text { Mexico City/ Minneapolis/ Philadelphia/ San } \\
\text { Francisco } \\
\text { Berlin/ Buenos Aires / Los Angeles/ Paris/ Rio de } \\
\text { Janeiro } \\
\text { Brussels/ Budapest/ Detroit/ Lausanne/ Mexico } \\
\text { City/ Tokyo } \\
\text { Brussels/ Detroit/ Vienna } \\
\text { Buenos Aires/ Detroit/ Lyon }\end{array}$ \\
\hline Phase 3 & $\begin{array}{l}1966 \\
1970 \\
1974 \\
1978 \\
1981\end{array}$ & $\begin{array}{l}1972 \\
1976 \\
1980 \\
1984 \\
1988\end{array}$ & \begin{tabular}{|l|} 
Munich \\
Montreal \\
Moscow \\
Los Angeles \\
Seoul
\end{tabular} & $\begin{array}{l}\text { Detroit/ Madrid/ Montreal } \\
\text { Los Angeles/ Moscow } \\
\text { Los Angeles } \\
\text { Nagoya }\end{array}$ \\
\hline Phase 4 & $\begin{array}{l}1986 \\
1990 \\
1993 \\
1997\end{array}$ & $\begin{array}{l}1992 \\
1996 \\
2000 \\
2004\end{array}$ & $\begin{array}{l}\text { Barcelona } \\
\text { Atlanta } \\
\text { Sydney } \\
\text { Athens }\end{array}$ & $\begin{array}{l}\text { Amsterdam/ Belgrade/ Birmingham/ Brisbane/ } \\
\text { Paris } \\
\text { Athens/ Belgrade/ Manchester/ Melbourne/ To- } \\
\text { ronto } \\
{\text { Berlin/ Istanbul/ Manchester/ Peking/ Brasilia }{ }^{\text {a/ }}} \\
\text { Milan }^{\text {a }} \\
\text { Buenos Aires/ Istanbul/ Cape Town/ Lille/ Rio de }_{\text {Janeiro/ Rome/ San Juan/ Seville/ Stockholm/ St. }} \text { Peorsburg }\end{array}$ \\
\hline Phase 5 & 2001 & $\begin{array}{l}2008 \\
2012\end{array}$ & $\begin{array}{l}\text { Peking } \\
\text { London }\end{array}$ & $\begin{array}{l}\text { Toronto/ Paris/ Istanbul/ Osaka/ Bangkok/ Cairo/ } \\
\text { Havanna/ KualaLumpur/ Seville } \\
\text { Paris/ Madrid/ New York/ Moscow/ Leipzig/ Is- } \\
\text { tanbul/ Rio de Janeiro/ Havanna }\end{array}$ \\
\hline
\end{tabular}

Source: Lyberg (1996); Schollmeier (2001); authors' own research.

Notes: ${ }^{a}$ The application was withdrawn shortly before the deciding vote; ${ }^{b}$ The city was chosen first; c The Olympic Games in 1916, 1940 and 1944 were not held due to the First and Second 
World Wars; ${ }^{\mathrm{d}}$ The horse-riding competitions of the 1952 Olympics were held separately due to Australia's strict regulations covering animal imports.

Illustration 1: Bids per Olympic Games

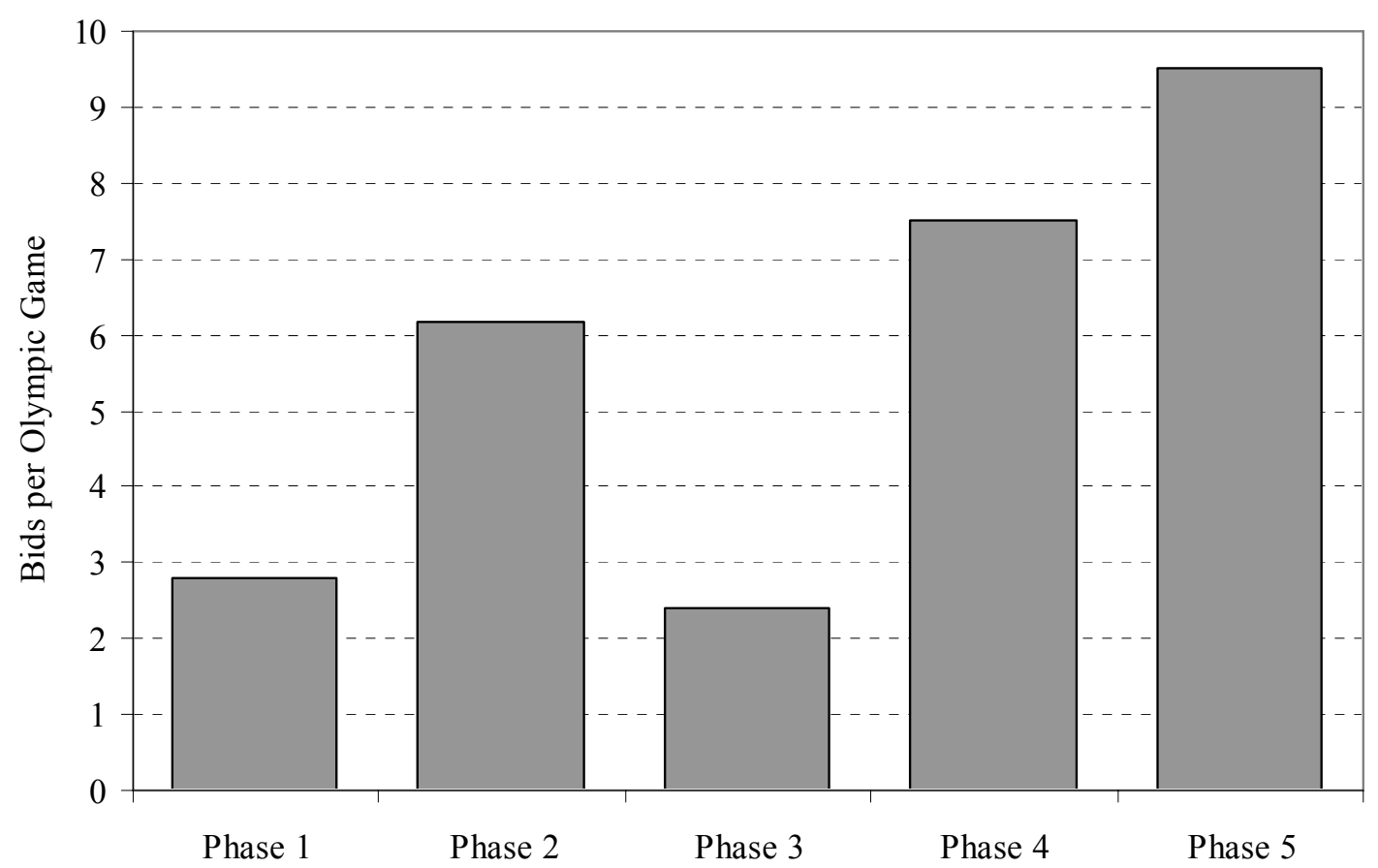

\section{Data, methods and results}

\subsection{Data}

The analysis of the characteristics of successful Olympic bids is based on the bids for the six Olympic Games from 1992 to $2012 .{ }^{10}$ The data for the empirical analysis is fundamentally taken from the bid books of the cities in question as well as from the reports of the IOC Evaluation Commission and relate to the year in which the IOC made the decision. In the case of incomplete data or macroeconomic data not included in the bid documentation, data from the World Bank was used. In cases in which the data pro-

\footnotetext{
10 The bids prior to the 1992 Games provide a significantly lower amount of information.
} 
vided by the bid books and the IOC Evaluation Commission differed, the latter source was used, since bid books sometimes tend to provide "embellished" information. ${ }^{11}$

The following empirical analysis makes use on the one hand of the factors for a successful bid as identified by Swart and Bob (2004), which can be quantified using the available data. To measure political support the results of public opinion polls conducted in the cities in question were used (SUPPORT). This data is taken from the bid books and/or from the IOC Evaluation Commission reports. The quantification of existing facilities took into account the extent to which the construction of the sporting venues had progressed. The proportion of completed venues requiring no further modification (COMP-READY), the venues requiring substantial reconstruction work or still under construction (IN-PROGRESS), as well as planned venues that would only be built on approval of the bid (PLANNED) was calculated in relation to the total of the Olympic sporting facilities mentioned in the bid books and the IOC reports. The number of available hotel beds within 50 minutes travelling time (BEDS) was taken from the bid books. ${ }^{12}$ Table 2 presents the average and median values of the data used.

Following the data requested by IOC (2004), the influencing factors were supplemented by additional variables on the sporting venue concept, the climatic situation and a number of socio-economic determinants. With regard to the sporting venue concept, variables on the operationalisation and quantification of the applicant cities' sporting concept were added. The average distance of the sporting venues from the Olympic Village in kilometres (DISTANCE), the number of planned Olympic Villages (NR OLYMP VILL) and the planned accommodation capacities of the Olympic Villages (CAP OLYMP VILL) were taken from the bid books and/or the IOC reports.

\footnotetext{
11 "What is written in the bid documents soon turns out to be pretty irrelevant." (N.N. 2004) who also points out one of the most recent cases of failing to keep the promises made in the bid books: shortly after approval of its bid for the 2010 Games, Vancouver decided to relocate the speed skating oval initially planned for the city center - to the waterfront. The International Broadcast Center was also to be relocated. Assuming rational decision-making processes on the part of the IOC members, the reduced validity of the bid book data should tend to lead to a limitation in the information content of the data, which has to be taken into account below when interpreting the results.

12 The IOC demands a minimum capacity of 40,000 beds (IOC 2004a, p. 57). In those cases in which the accommodation capacities in the bid books were cited via numbers of hotel rooms, this figure was multiplied by a factor of 1.8. Cf. Lexington (2002, p. 91) for a justification of this conversion factor.
} 
The national purchasing-power-adjusted per capita GDP (GDP) as defined by the World Bank was included as a socio-economic determinant and adjusted for inflation based on the year 1995 in US-\$. In addition the unemployment rate (UR) and the inflation rate (INFL) were also tested. The population size of the applicant country (pop) was also included, which can be regarded as an indicator for its political power.

Finally, in order to take climatic aspects into account, the average temperature (TEMP) and relative humidity (HUMID) during the period envisaged for the Games were also taken into consideration. This data was taken from the bid books of the cities in question and the Evaluation Commission reports.

Table 2: Descriptive Statistics

\begin{tabular}{|c|c|c|c|}
\hline & & Successful bids & Unsuccessful bids \\
\hline \multirow{2}{*}{$\begin{array}{c}\text { GDP } \\
\text { (in US\$ }{ }_{1995 ;} \text { PPP) }\end{array}$} & Mean & 15,143 & 13,180 \\
\hline & Median & 13,565 & 14,438 \\
\hline \multirow{2}{*}{$\begin{array}{l}\text { Unemployment rate } \\
\text { (in \%) }\end{array}$} & Mean & 10.9 & 10.0 \\
\hline & Median & 10.7 & 8.7 \\
\hline \multirow{2}{*}{$\begin{array}{l}\text { Rate of inflation } \\
\text { (in \%) }\end{array}$} & Mean & 4.2 & 25.0 \\
\hline & Median & 4.3 & 4.3 \\
\hline \multirow{2}{*}{ Public support (in \%) } & Mean & 90.0 & 78.5 \\
\hline & Median & 90.0 & 80.5 \\
\hline \multirow{2}{*}{$\begin{array}{c}\text { Distance of the sporting } \\
\text { venues to the Olympic } \\
\text { Village (in km) }\end{array}$} & Mean & 12.07 & 16.72 \\
\hline & Median & 9.44 & 16.38 \\
\hline \multirow{2}{*}{$\begin{array}{l}\text { Completed Venues } \\
\text { (in \%) }\end{array}$} & Mean & 52.8 & 44.9 \\
\hline & Median & 50.0 & 43.5 \\
\hline \multirow{2}{*}{$\begin{array}{l}\text { Venues under } \\
\text { construction } \\
\text { (in \%) }\end{array}$} & Mean & 21.2 & 24.5 \\
\hline & Median & 16.7 & 20.5 \\
\hline \multirow{2}{*}{$\begin{array}{l}\text { Planned venues } \\
\quad \text { (in \%) }\end{array}$} & Mean & 26.0 & 30.4 \\
\hline & Median & 26.0 & 30.8 \\
\hline \multirow{2}{*}{$\begin{array}{l}\text { Accommodation capac- } \\
\text { ity (in hotel beds) }\end{array}$} & Mean & 91,500 & 67,613 \\
\hline & Median & 88,308 & 49,115 \\
\hline
\end{tabular}

Source: The Worldbank Group (2004), IOC (1986, 1990, 1993, 1997, 2001, 2004a), United Nations Development Programme (2004), Bidding Committees of the Cities, authors' own calculations. 


\subsection{Methods and results}

Binary logistical regression can suitably analyse the yes/no decisions that determine whether an applicant city's bid is successful or not (Bühl and Zöfel 2000, p. 354). In view of the large number of potential influencing factors and the limited number of observations, the method of forward selection was used here, in which by referring initially only to the constant, those variables were successively included which display the highest explanatory value for the dependent variable. This method also incidentally takes any problems of multicollinearity into account. In view of the small sample the criterion for the inclusion of the independent variables was set to 0.1. Table 3 illustrates that the process of determination of the regression equation can already be broken off after the fourth step. The four variables that, in accordance with the chi-square distributed Wald statistic, have a significant influence on a bid's chances of success are the average distance of the sporting venues to the Olympic Village (Distance), the unemployment rate (UR), the average temperature (TEMP) as well as the national population size (POP).

Table 3: Results

\begin{tabular}{|l|c|c|c|c|c|}
\hline & $\beta_{\mathrm{i}}$ & $\begin{array}{c}\text { Standard } \\
\text { error }\end{array}$ & Wald & Sig. & Exp $\left(\mathrm{B}_{\mathrm{i}}\right)$ \\
\hline UNEMPLOYM & 0.231 & 0.124 & 3.438 & 0.064 & 1.259 \\
\hline DISTANCE & -0.440 & 0.215 & 4.203 & 0.040 & 0.644 \\
\hline TEMP & 0.458 & 0.235 & 3.797 & 0.051 & 1.581 \\
\hline POP & 0.000 & 0.000 & 4.173 & 0.041 & 1.000 \\
\hline CONSTANT & -10.108 & 6.088 & 2.757 & 0.097 & 0.000 \\
\hline
\end{tabular}

Source: Authors' own calculations.

The effect coefficients in column 6 of Table 3 indicate with $\operatorname{Exp}\left(\mathrm{B}_{\mathrm{i}}\right)>1$ for the variables unemployment and temperature their positive influence on the probability of being 
awarded the Olympic Games. ${ }^{13}$ For unemployment this is initially surprising. Seen against the background of the high unemployment rates prevalent in the cities of Barcelona $(18.0 \%)$, Athens $(19.0 \%)$ and Sydney $(10.7 \%)$ at the time they were awarded the Games, this result becomes easier to understand. Applicant cities with employment problems possibly put particularly intensive effort into acquiring the Olympic Games. As for the temperatures, it must be emphasised explicitly that the information gleaned from the quasi-linear relationship relates to the range of the data used here (and not, for example, to significantly higher temperatures in cities and periods of time, for which no bids exist). Non-linear relationships may result from the inclusion of temperatures that go beyond the scope of the applicant cities 1996 until 2012. The effect coefficient $B_{i}=1$ for the size of population means that the probability of a successful bid does not change with the size of the population.

In addition to the effects of the individual determinants the overall explanatory power of the model is also of interest. In order to assess the goodness of fit of our model we may use the $\mathrm{Chi}^{2}$-distributed difference of the negatively doubled values of the logarithm of the likelihood function of the (above-described final) estimation model $\left(-2 L_{\text {fin }}=17.3\right)$ and the model that only contains the constant $\left(-2 L_{\text {const }}=30.9\right)$ which is shown as significant (Bühl and Zöfel 2000, p. 357). According to Nagelkerke's measure the explained variance stands at $52.8 \%$ (Diaz-Bone and Künemund 2003, p. 13).

A further test of the goodness of fit of an estimated logistical model results from the evaluation of the success of the prognosis. The classification table shown in Table 4 illustrates the overall explanatory power provided by the current regression model. The model correctly predicts the result of the application process in $93 \%$ of cases. This high figure is however relativised by the fact that whilst the model was able to predict failure in over $97 \%$ of cases, it was only able to correctly predict success in $60 \%$ of cases. The model thus achieves a high degree of explanatory power in particular due to the high level of unsuccessful bids (38 of 43 cases) (Hosmer and Lemeshow 1989, p. 146 et seq.).

\footnotetext{
${ }^{13}$ On the validity and interpretation of effect coefficients cf. for example Urban (1993, p. 12).
} 
Table 4: Prognosis value of the estimation model

\begin{tabular}{|c|c|c|c|c|}
\hline \multicolumn{2}{|c|}{} & \multicolumn{2}{|c|}{ Predicted by the model } & \multirow{2}{*}{ Percentage } \\
\cline { 3 - 4 } \multicolumn{2}{c|}{} & $\begin{array}{c}\text { Negative } \\
\text { decision }\end{array}$ & $\begin{array}{c}\text { Positive } \\
\text { decision }\end{array}$ & \\
\hline \multirow{2}{*}{ IOC decisions } & $\begin{array}{c}\text { Negative } \\
\text { decision }\end{array}$ & 37 & 1 & 97.4 \\
\cline { 2 - 4 } & $\begin{array}{c}\text { Positive } \\
\text { decision }\end{array}$ & 2 & 3 & 60.0 \\
\hline Total & & & & 93.0 \\
\hline
\end{tabular}

Source: Authors' own calculations.

This discrepancy might be explained by the fact that the determinants analysed here quantified the necessary conditions for success, but not, as yet, the sufficient conditions. Applicants that fail to adequately fulfil these criteria can be determined to have poor chances of success. If an applicant city fulfils all the necessary conditions the other unquantified historical, political, ${ }^{14}$ psychological and application campaign related factors hinted at by Swart and Bob (2004) may play an important role. It will be task for future analyses to empirically test the role of the quality of the cities' presentations before the IOC plenum, the personal preferences of the IOC-members, ${ }^{15}$ lobbyism and the potentially more problematic forms of gaining influence.

\section{Conclusion}

The number of bids for the Summer Olympics has risen significantly since the economic successes of the Games in L.A. in 1984 and Seoul in 1988. At the same time the expenditure of resources on the bid campaigns has also risen. This paper examines the probabilities of success of bid campaigns on the basis of quantified determinants. The analysis is based on a total of 43 bids for the Summer Olympics between 1996 and 2012.

14 Historical aspects could have played a role in the case of Athens 2004, whilst political effects may have been of significance in the case of Peking 2008.

15 These preferences must not correspond to the continental origins of the IOC members, cf. Swart and Bob (2004) for the case of Cape Town's bid for the 2004 Games. 
The average distance of the sports venues to the Olympic Village (distance) has a significantly negative influence on chances of success. The average temperatures in the host cities during the Olympic Games has a positive influence, whereby it must be emphasised that the information provided by the quasi-linear relationship relates to the range of the data used here (and not, for example, to significantly higher temperatures in cities and periods of time, for which no bids exist). The equally significantly positive influence of unemployment could stem from the particularly intensive effort put into acquiring the Olympic Games on the part of applicant cities with employment problems. The variable "unemployment" thus might possibly be a proxy variable for another hitherto unquantified variable that measures the "bid pressure" in the applicant cities.

The analysis of the goodness of fit showed that with around $97 \%$ of predictions correct the model used was considerably more accurate in predicting unsuccessful bids than successful ones (60\%). Future works that provide better models of successful bids could also quantify and take into consideration historical, political, psychological and bid campaign related factors.

\section{Literature}

Andranovich, G., M. J. Burbank and C.H. Heying (2001), Olympic Cities: Lessons learned from Mega-Event Politics, in: Journal of Urban Affairs 23, 2, 113-131.

Baade, R.A. and V. Matheson (2002), Bidding for the Olympics: Fool's Gold?, in: C. Barros, M. Ibrahímo and S. Szymanski [eds.], Transatlantic Sport: The Comparative Economics of North America and European Sports, London; p. 127-151.

Bidding Committee Amsterdam 1992 (1985), Bid book, Vol. 1-3, Amsterdam.

Bidding Committee Athens 1996 (1989), Bid book, Vol. 1-3, Athens.

Bidding Committee Athens 2004 (1995), Bid book, Vol. 1-3, Athens.

Bidding Committee Atlanta 1996 (1989), Bid book, Vol. 1-3, Atlanta.

Bidding Committee Barcelona 1992 (1984), Bid book, Vol. 1-3, Barcelona.

Bidding Committee Beijing 2000 (1993), Bid book, Vol. 1-3, Peking.

Bidding Committee Beijing 2008 (2001), Candidature File, Vol. 1-3, Peking.

Bidding Committee Belgrade 1992 (1985), Bid book, Vol. 1-3, Belgrad. 
Bidding Committee Belgrade 1996 (1989), Bid book, Vol. 1-3, Belgrad.

Bidding Committee Berlin 2000 (1993), Bid book, Vol. 1-3, Berlin.

Bidding Committee Birmingham 1992 (1985), Bid book, Vol. 1-3, Birmingham.

Bidding Committee Brasilia 2000 (1993), Bid book, Vol. 1-3, Brasilia.

Bidding Committee Brisbane 1992 (1985), Bid book, Vol. 1-3, Brisbane.

Bidding Committee Buenos Aires 2004 (1995), Bid book, Vol. 1-3, Buenos Aires.

Bidding Committee Cape Town 2004 (1997), Bid book, Vol. 1-3, Kapstadt.

Bidding Committee Havana 2012 (2003), Applicant City Report for the 2012 Olympic Games, Havana.

Bidding Committee Istanbul 2000 (1993), Bid book, Vol. 1-3, Istanbul.

Bidding Committee Istanbul 2004 (1996), Bid book, Vol. 1-3, Istanbul.

Bidding Committee Istanbul 2008 (2001), Candidature File, Vol. 1-3, Istanbul.

Bidding Committee Istanbul 2012 (2003), The Meeting of Continents - Istanbul 2012 Applicant City, Istanbul.

Bidding Committee Leipzig 2012 (2003), Applicant City Report for the 2012 Olympic Games, Leipzig.

Bidding Committee Lille 2004 (1996), Bid book, Vol. 1-3, Lille.

Bidding Committee Manchester 1996 (1989), Bid book, Vol. 1-3, Manchester.

Bidding Committee Manchester 2000 (1993), Bid book, Vol. 1-3, Manchester.

Bidding Committee Melbourne 1996 (1989), Bid book, Vol. 1-3, Melbourne.

Bidding Committee Osaka 2008 (2001), Candidature File, Vol. 1-3, Osaka.

Bidding Committee Paris 1992 (1985), Bid book, Vol. 1-3, Paris.

Bidding Committee Paris 2008 (2001), Candidature File, Vol. 1-3, Paris.

Bidding Committee Rio de Janeiro 2004 (1995), Bid book, Vol. 1-3, Rio de Janeiro.

Bidding Committee Rio de Janeiro 2012 (2003), Applicant City Report for the 2012 Olympic Games, Rio de Janeiro.

Bidding Committee Roma 2004 (1995), Bid book, Vol. 1-3, Rom.

Bidding Committee San Juan 2004 (1996), Bid book, Vol. 1-3, San Juan.

Bidding Committee Sevilla 2004 (1996), Bid book, Vol. 1-3, Sevilla. 
Bidding Committee St. Petersburg 2004 (1996), Bid book, Vol. 1-3, St. Petersburg.

Bidding Committee Stockholm 2004 (1995), Bid book, Vol. 1-3, Stockholm.

Bidding Committee Sydney 2000 (1991), Bid book, Vol. 1-3, Sydney.

Bidding Committee Toronto 1996 (1990), Bid book, Vol. 1-3, Toronto.

Bidding Committee Toronto 2008 (2001), Candidature File, Vol. 1-3, Toronto.

Bühl, A., and P. Zöfel (2000), SPSS Version 10, 7. Auflage, München.

Diaz-Bone, R., and H. Künemund (2003), Einführung in die binäre logistische Regression, Mitteilungen aus dem Schwerpunktbereich Methodenlehre, Berlin.

Greenberg, S. (2003), Whitaker's Olympic Almanack 2004 - The essential Guide to the Olympic Games, London.

Guttmann, A. (1992), The Olympics: A History of the Modern Games, University of Illinois Press, Chicago.

Hosmer, D. W. and S. Lemeshow (1989), Applied Logistic Regression, New York.

Hotchkiss, J., R.E. Moore and S.M. Zobey (2003), Impact of the 1996 Summer Olympic Games on Employment and Wages in Georgia, in: Southern Economic Journal 69, p. 691-704.

IOC (1986), Report, Study and Evaluation Commission for the Preparation of the Games of the XXVth Olympiad - 1992, Lausanne.

IOC (1990), Report, Study and Evaluation Commission for the Preparation of the Games of the XXVIth Olympiad - 1996, Lausanne.

IOC (1993), Report - IOC Enquiry Commission for the Games of the XXVII Olympiad 2000, Lausanne.

IOC (1997), Report of the IOC Evaluation Commission for the Games of the XXVIII Olympiad in 2004, Lausanne.

IOC (2001), Report of the IOC Evaluation Commission for the Games of the XXIX Olympiad in 2008, Lausanne.

IOC (2004a), Games of the XXX Olympiad in 2012 - Report by the IOC Candidature Acceptance Working Group to the IOC Executive Board, Lausanne.

Lexington Consulting GmbH (2002), Zentrale Wirtschaftlichkeitsaspekte der Bewerbung Hamburgs um die Olympischen Spiele im Jahr 2012, Hamburg.

Liu, X. (1998), Der Weg der Dritten Welt in die Olympische Bewegung, in: M. Lämmer [ed.], Studien zur Sportgeschichte, Vol. 5, Sankt Augustin. 
Lyberg, W. (1996), Fabulous 100 Years of IOC. Facts-figures and much, much more, Lausanne.

Maennig, W. (2002), On the economics of doping and corruption in international sports, in: Journal of Sports Economics 3, p. 61-89.

n.n. (2004), Things in Vancouver..., in: Sport Intern, 14/15, Aug. 5th, 2004, p. 3.

Preuß, H. (2004), The Economics of Staging the Olympics, Cheltenham: Edward Elgar

Riordan, J., B. Lowe and L. Nikishkinov (1980), Soviet commitment and the success of the XXII Olympic Games, Moscow 1980, in: Review of Sport and Leisure 5, p. 21-34.

Ritchie, J.R.B. and J. Yangzhou (1987), The Role and Impact of Mega-Events and Attractions on National and Regional Tourism: A Conceptual and Methodological Overview, Paper for 37th AIST Congress, Association Internationale d'Experts Scientifiques du Tourisme, August, Calgary.

Schauenberg, B. (1992), Die Hare-Regel und das IOC, in: Zeitschrift für Betriebswirtschaftliche Forschung Zfbf 44, p. 426-444.

Scherer, K. A. (1995), 100 Jahre Olympische Spiele. Idee, Analyse und Bilanz, Dortmund.

Schollmeier, P. (2001), Bewerbungen um Olympische Spiele. Von Athen 1996 bis Athen 2004, Köln.

Spilling, O.R. (1996), Mega-Event as a Strategy for Regional Development: The Case of the 1994 Lillehammer Winter Olympics; in: Entrepreneurship \& Regional Development 8, p. 321-343.

Tews, M.-K. (1993): The Mega-event as an Urban Redevelopment Strategy: Atlanta Prepares for 1996 and Beyond, Mimeograph, New Orleans: College of Urban and Public Affairs, October

The Worldbank Group (2004), Data Query System, <http://devdata.worldbank. org/query/> , 10.11.2004.

United Nations Development Programme (2004), Human Development Report 2004 - Cultural Liberty in today's diverse world, $<$ http://hdr.undp.org/reports/global/2004/pdf/hdr04_HDI.pdf >, 12.01.2005

Urban, D. (1993), Logit-Analyse - Statistische Verfahren zur Analyse von Modellen mit qualitativen Response-Variablen, Stuttgart.

Waldbröl, H.-J. (2003), „Leipzig ist nicht zu klein für Olympische Spiele“ IOC-Präsident Jaques Rogge im F.A.Z.-Sportgespräch: Athen wird fertig - ist die Wada fix und fertig?, in F.A.Z. (13.06.2003), Frankfurt. 


\section{Hamburg Working Paper Series in Economic Policy}

(Download: http://www.uni-hamburg.de/fachbereiche-einrichtungen/fb03/iiw/workingpaper.html)

01/2005 FEDDERSEN, A. / MAENNIG, W.: Trends in Competitive Balance: Is there Evidence for Growing Imbalance in Professional Sport Leagues?, January 2005.

02/2005 SIEVERS, T.: Information-driven Clustering - An Alternative to the Knowledge Spillover Story, February 2005.

03/2005 SIEVERS, T.: A Vector-based Approach to Modeling Knowledge in Economics, February 2005.

04/2005 BÜTTNER, N. / MAENNIG, W. / MENßEN, M.: Zur Ableitung einfacher Multiplikatoren für die Planung von Infrastrukturkosten anhand der Aufwendungen für Sportstätten - eine Untersuchung anhand der FußballWM 2006, May 2005.

01/2006 FEDDERSEN, A.: Economic Consequences of the UEFA Champions League for National Championships - The Case of Germany, May 2006.

02/2006 FEDDERSEN, A.: Zur Verwendung von Markov-Ketten bei der Messung der langfristigen Wettbewerbsintensität in Teamsportligen, July 2006.

03/2006 FEDDERSEN, A. / VÖPEL, H.: Staatliche Hilfen für Profifußballclubs in finanziellen Notlagen? - Die Kommunen im Konflikt zwischen Imageeffekten und Moral-Hazard-Problemen, September 2006.

01/2007 AHLFELD, G. / MAENNIG, W.: Award-Winning Architecture and Urban Revitalization: The Case of "Olympic Arenas" in Berlin-Prenzlauer Berg, January 2007.

02/2007 FEDDERSEN, A. / MAENNIG, W. / ZIMMERMANN, P.: How to Win the Olympic Games - The Empirics of Key Success Factors of Olympic Bids, January 2007.

03/2007 AHLFELD, G. / MAENNIG, W.: The Impact of Sports Arenas on Locational Attractivity: Evidence from Berlin, February 2007. 